\title{
Polish Connections to the Hajj between Mystical Experience, Imaginary Travelogues, and Actual Reality
}

\author{
Bogusław R. Zagórski
}

The main purpose of this chapter is to present the legend of a mystical travel to Mecca as was preserved in the (mainly oral) tradition of the Polish-Lithuanian Tatars and another literary text on the Hajj from the nineteenth century. The first travel is associated with a local holy man, a simple countryside dweller, who through his exceptional piety achieved the faculty of translocating in his body to Mecca where he eventually met his fellow countryman to the latter's great surprise and amazement. The second travel is meant as a nonfiction imaginary travel report by Ignacy Żagiell, which appeared in 1884 (and reprinted in 2012). His imaginary travel story gained a certain notoriety and popularity in the history of Polish travel writing and in Polish literature in general. However, a closer examination of the text and of the alleged circumstances reveals the fictitious character of that report.

Both accounts testify to a wide interest in Poland in the nineteenth century, extending also to non-Muslims, in Islamic culture and traditions. It should be borne in mind that Poland was a vast country, but at that time without sovereignty, having fallen since 1795 under the Prussian, Austrian (subsequently-Austro-Hungarian), and Russian empires. The Russian territories included the areas of pre-partition Poland which hosted a permanent Muslim sedentary population.

Polish Muslims (so-called Polish or Lithuanian Tatars, also Belarussian Tatars, sometimes Polish-Lithuanian Tatars or Lithuanian-Polish Tatars, as well as Lipka or Lipka Tatars) lived since the 14th century in a region with a multiethnic conglomerate of peoples, who witnessed changing political status several times, resulting in uprisings, wars, ethnic cleansings, mass murders, political repressions, and resettlements. ${ }^{1}$ Villages and towns were burnt and ruined.

1 On the history of Islam in Poland see, for example, Harry T. Norris, Islam in the Baltic: Europe's Early Muslim Community (London-New York: I.B. Tauris, 2009), Piotr Borawski, Tatarzy w dawnejRzeczypospolitej (Warszawa: Ludowa Spółdzielnia Wydawnicza, 1986), Piotr Borawski 
Poland, or a Polish-Lithuanian Commonwealth in historical times, was an asylum and a homeland for local Muslims during a period of more than 6oo years, which was a unique situation in Europe. Nowadays Muslims in Poland are mostly of Tatar origins, recent migrants from Arab and other Muslim countries, as well as native converts. ${ }^{2}$

The two relations need to be put, however, in a wider historical context of actual travels to Mecca from the Polish lands.

\section{Risale-i Tatar-ILeh-The Only Remnant of an Old Tradition?}

As for the Polish connection to the Hajj, we do not have any direct evidence indicating the travel of Tatar Muslims to Mecca in pre-modern times. However, there is a unique remaining text connected to the Hajj, a somewhat mysterious Ottoman document under the title Risāleh-iTätār-ı Leh (An Account of the Polish Tatars). It refers to a hajj journey by three unnamed Polish Tatars who travelled to Mecca in 1558. On their way, they passed through Istanbul in order to pay their tribute to Sultan Süleyman I (1494-1566), as the Commander of the Faithful. During their stay in Istanbul, they were asked by the Grand Vizier, Rüstem Paşa (d. 1561), to write an account of the history and status of Muslims in the Polish-Lithuanian regions. With the help of some local writers, they composed this Ottoman text, which was only published three hundred years later by the Polish Orientalist Antoni Muchliński (1808-1877). ${ }^{3}$ A debate over its originality ensued, which possibly could be resolved through direct examination of the original manuscript, but its present whereabouts remain unknown. ${ }^{4}$

A terminological dilemma arose, among others, in respect of a name applied to the ethnic group, the subject of the account. The Ottoman text was citing Tatar-ILeh, the Polish Tatars, in the same way as it was common in other Otto-

and Aleksander Dubiński, Tatarzy polscy. Dzieje, obrzędy, legendy, tradycje (Warszawa: Iskry, 1986), Jan Tyszkiewicz, Tatarzy na Litwie i w Polsce. Studia z dziejów XIII-XVIII w. (Warszawa: Państwowe Wydawnictwo Naukowe, 1989), Jan Tyszkiewicz, Z historii Tatarów polskich 17941944 (Pułtusk: Wyższa Szkoła Humanistyczna, 2002), Ali Miśkiewicz, Tatarzy polscy 1918-1939. Życie spoteczno-kulturalne i religijne (Warszawa: Państwowe Wydawnictwo Naukowe, 199o).

2 See KatarzynaGórak-Sosnowska, ed., Muslims in Poland and Eastern Europe: Widening the European Discourse on Islam (Warsaw: University of Warsaw, Faculty of Oriental Studies, 2011).

3 Antoni Muchliński (ed.), Zdanie sprawy o Tatarach litewskich przez jednego z tych Tatarów ztożone suttanowi Sulejmanowi w r. 1558: Risale-i Tatarı Leh (Wilno, 1858).

4 Krzysztof Grygajtis, "Obraz Tatarszczyzny litewskiej na dworze tureckim w połowie XVI wieku," Studia z dziejów nowożytnych (Wrocław 1988), 25-40. 

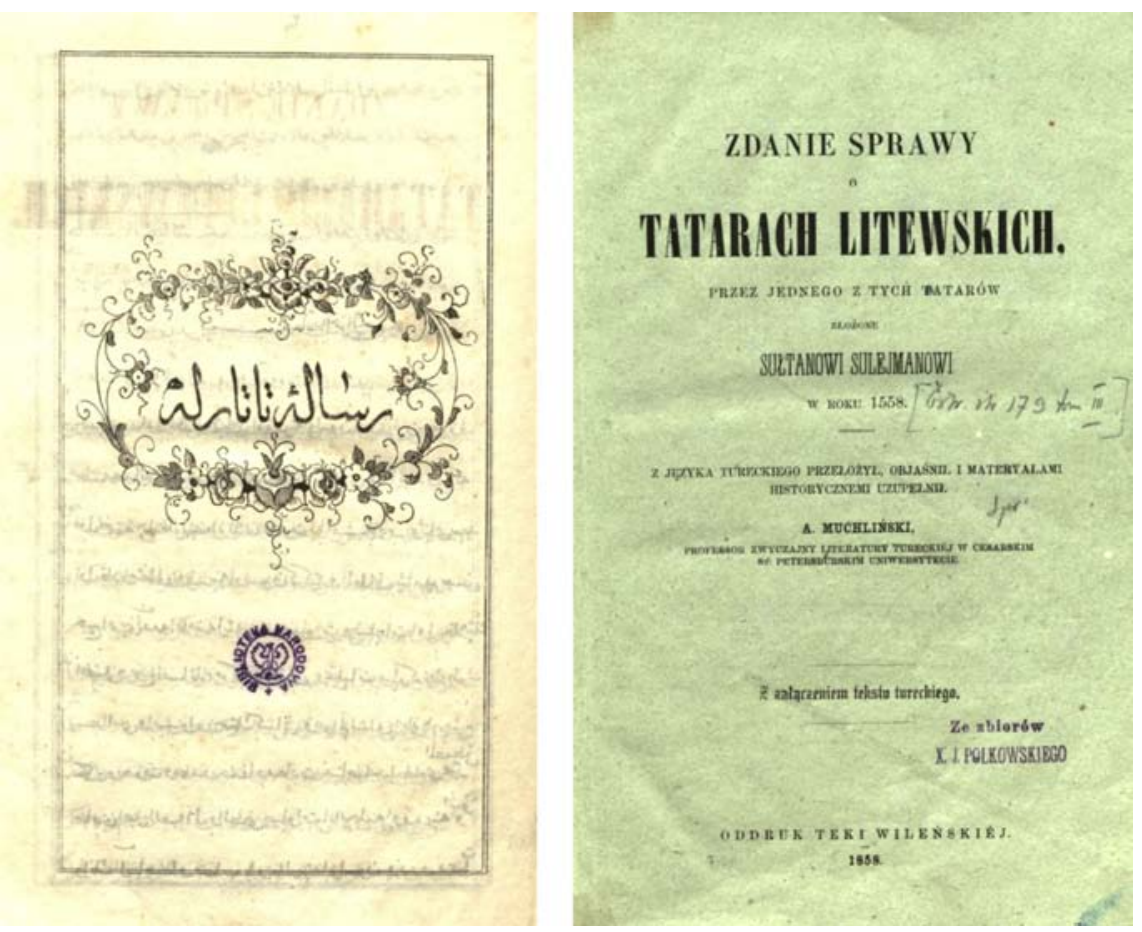

FIgURe 6.1 Risale-i Tatar-1 Leh, in Ottoman Turkish and in Polish NATIONAL LIBRARY (BIBLIOTEKA NARODOWA), WARSAW

man writings to say: Memalik-iLeh, for the Polish Domains (State), Kral-ILeh, the Polish King, etc. Leh, Polish, or Lehistan, Poland, were not connected with that kind of modern understanding of nationality as we perceive it today. In the Ottomans' eyes Lithuania at that time was just a constituent part of a greater polity called Poland in toto. Furthermore, even if in Turkish the name for that group was Tatar-1Leh, in Polish it was expressed as Tatarzylitewscy-Lithuanian Tatars, because that was the term in common use in Polish. And precisely that name was used by Muchliński in his publication. To be precise, it did not refer to Lithuanian ethnicity and language, but to the Grand Duchy of Lithuania, a wide geographical and political expanse, in which ethnic Lithuanians, historical givers of the name, constituted only a tiny minority.

A new approach to the question of the document published by Muchliński is presented by Michael Połczyński in his freshly appearing work. ${ }^{5}$ Treating the

5 Michael Połczyński, "Seljuks on the Baltic: Polish-Lithuanian Muslim Pilgrims in the Court of Ottoman Sultan Süleyman I," Journal of Early Modern History 19 (2015): 1-29. 
Risale-i Tatar-ILeh as an authentic source from the past, the author develops his own contextual ideas about historical events presented in the text and about circumstances in which the document was produced. The Hajj is however not the core subject of the treatise.

\section{Tenuous Indications}

In addition to the above-mentioned early travel, a small Belorussian-Polish manuscript preserved in the National Library of Lithuania in Vilnius (produced locally, probably in the seventeenth or eighteenth century) contains a peculiar combination of texts noted in Arabic script. ${ }^{6}$ It is a concise travelogue which includes description of a route from Lithuania to Istanbul, together with a travel conversation handbook in Belarussian-Polish, Turkish, and Romanian. Most probably it could be made for the use of wandering Tatar merchants in the region. However, it might have also been a practical guidebook for potential pilgrims. If this last assumption were true, we might suggest that Muslims from the Grand Duchy of Lithuania went on Hajj in the pre-modern and early modern periods. ${ }^{7}$ Some authors, basing their arguments on fragmentary and equivocal evidence, advance an idea that in the period between the sixteenth and eighteenth century, a few Muslim Tatars from Poland could have really performed the Hajj. ${ }^{8}$

In this context, the mystical travel to Mecca that exists in the local Tatar tradition may constitute evidence of a longing for and a strong mental striving towards the accomplishment of the Hajj, that was not technically possible (or at least extremely difficult) in the past and which in a way was transferred from reality to a cherished dream, founding its realization in popular beliefs. The story has long existed in oral transmission, how long-we cannot say, but it was first registered in the nineteenth century.

6 Tadeusz Majda, “Turkish-Byelorussian-Polish Handbook," Rocznik Orientalistyczny xLIX, No. 2 (1994): 139-158.

7 For possible Polish pilgrims to Mecca, see Agnieszka Bakalarz, Polaków odkrywanie Arabii Saudyjskiej. (Kraków: Księgarnia Akademicka, 2005); Marek M. Dziekan, Polacy a świat arabski. Stownik biograficzny. (Gdańsk: Niezależne Wydawnictwo "Rocznik Tatarów Polskich," 1998), Jerzy S. Łątka, Stownik Polaków w Imperium Osmańskim i Republice Turcji (Kraków: Księgarnia Akademicka, 2005), and Jan Reychman, Podróżnicy polscy na Bliskim Wschodzie w XIX w. (Warszawa: "Wiedza Powszechna," 1972).

8 Agnieszka Bakalarz, Polaków odkrywanie Arabii Saudyjskiej (Kraków: Księgarnia Akademicka, 2005), 40-42. 


\section{The Story of Kontuś}

This folkloric oral story, in itself full of diverging and parallel information, is quite widespread as an element of Polish Orientality and is repeated in various versions in almost all existing monographs on the Polish Tatars. ${ }^{9}$ The motive line starts with the Polish king Stefan Batory (originally a Transilvanian prince, in Hungarian: Báthory István, 1533-1586) who was once hunting in the vicinity of Nowogródek, what was then in Eastern Poland, on the territory of the Grand Duchy of Lithuania (at present that area belongs to Belarus). The king's Muslim Tatar gamekeeper (towczy in Polish) was charmed with the land in which they were hunting; and in reward for his outstanding services he was given that land by the king. The new landlord established there a village named after his function Łowczyce, which later carried a new family name Łowczycki originating from that toponym.

An existing mosque in the village is dated either from 1558 or 1688 , and in the neighboring Muslim cemetery (mizar) there is a much venerated tomb, allegedly containing the earthly remains of Ewlija Kontuś (or Kontej, or Kuntuś). Kontuś during his lifetime was a poor and outstandingly pious boy, working for the Łowczycki family as a shepherd.

Łowczycki was in trouble. His only daughter under the influence of Jesuit Fathers converted to Christianity and married, against the will of her father, a Christian nobleman. The landlord, in expiation for his daughter's sinful conduct, decided to ask God's mercy at the Islamic Holy City of Mecca. He sold a part of his land properties in order to perform the Hajj. When he was in Mecca, his funds became exhausted and Łowczycki did not know how to return to his home and family. He started praying in al-Haram al-Shariff, supplicating God for help (another version says it was at the tomb of the Prophet, who is in fact buried in Medina, but that information among the Tatars was often mistaken). ${ }^{10}$ Somebody overheard his humble prayers, approached and said:

No handwritten copy of this story has been found in the so far explored collections of manuscripts originating from the circles of the Polish (Lithuanian, Belarussian) Tatars. The story of Kontuś presented here was established after versions cited in: Aleksander Dubiński, “Une légende des Tatars de Pologne." In Quand le crible était dans la paille: hommage à Pertev Naili Boratav, ed. by Rémy Dor and Michèle Nicolas (Paris: G.-P. Maisonneuve et Larose, 1978), 169-175, and Piotr Borawski and Aleksander Dubiński, Tatarzy polscy. Dzieje, obrzędy, legendy, tradycje (Warszawa: Iskry, 1986); also see Agnieszka Bakalarz, Polaków odkrywanie Arabii Saudyjskiej. (Kraków: Księgarnia Akademicka, 2005), 3637 .

The question where exactly the tomb of Muhammad was placed was not only mistaken 


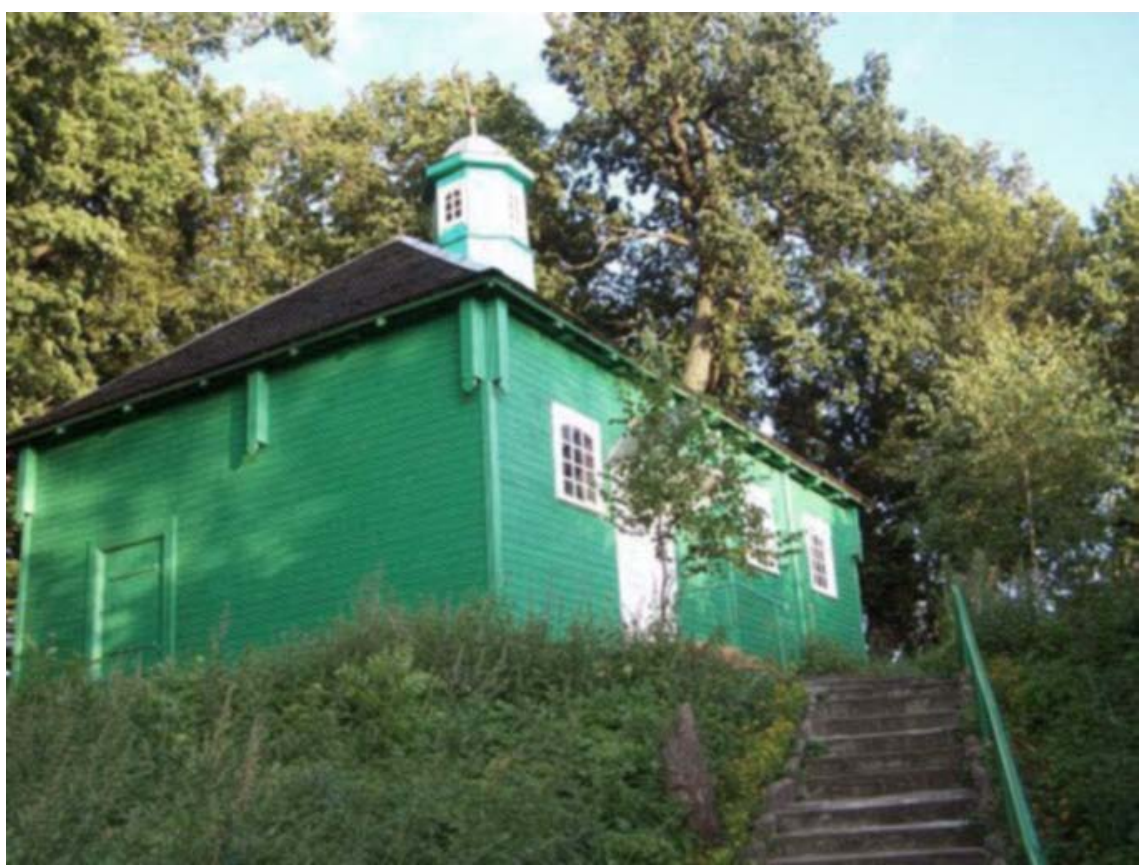

FIGURE 6.2 The mosque in Łowczyce (Western Belarus), homeland of Kontus MARIUSZ PROSKIEŃ

"There is your home country fellowman praying at the tomb of the Prophet nearby who arrives here every day. Meet him and ask him for help." To his great amazement Łowczycki discovered there his own poor herdsman Kontuś. Kontuś promised Łowczycki to offer his help on the condition of not telling anyone how they met and not revealing the secret of their travel home to anybody until death. Then he hugged him, asked him to close his eyes and in a moment they were both back in their village. Another version says that it was an angel who carried the two men to Łowczyce. Also there is a divergence on the way of how Kontuś travelled: it was either in a dream or in reality.

Łowczycki did not keep the secret and told the miraculous story to his importunate wife, what could appear dangerous to Kontuś' life and terminate it, but he survived somehow. Another version says that Łowczycki kept his

by the Tatars. Erroneous localization of that tomb in Mecca was repeatedly appearing in various European relations of the Islamic Holy Places, for example, see F.E. Peters, The Hajj: The Muslim Pilgrimage to Mecca and the Holy Places (Princeton, New Jersey: Princeton University Press, 1994), 80-81. 


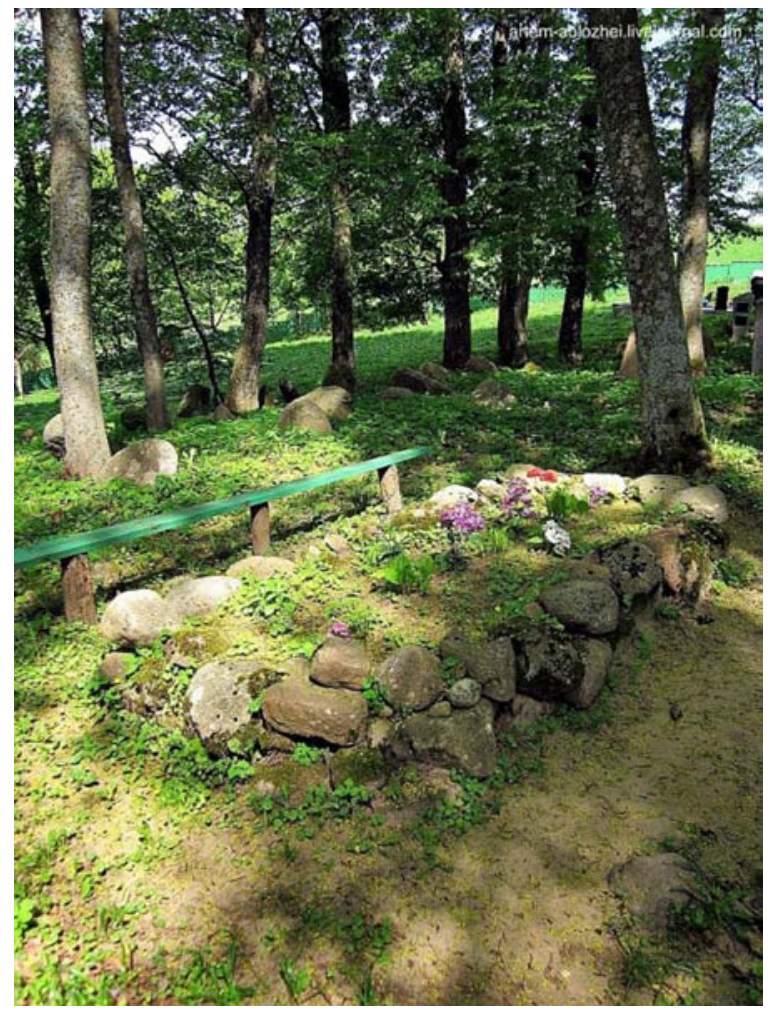

FIGURE 6.3

The grave of Kontus in the

Muslim cemetery of Łowczyce ARTEM ABLOZHEI

secret and Kontuś lived on for many years. All versions underline the good treatment Łowczycki reserved to his herdsman until the end of his days.

When Kontuś died after his long life in a modest barn, it is asserted that a "heavenly light" appeared over it. When he was buried, his grave never collapsed and always looks fresh, and two giant oak trees are protecting its head side. The healing properties of the grave gained wide notoriety. Many faithful people, even from far away locations, make pilgrimage to that last abode of Kontuś' earthly remains, seeking protection and benediction. ${ }^{11}$

The legend of EwlijaKontuś, with a little enigma of his unusual name (most likely of Turkic origin; several etymological explanations were proposed, none of them seemingly conclusive), is perhaps reminiscent of the Fufi holy men enjoying widespread cult popularity among Eastern European Muslims. They

11 Ryszard Vorbrich, "Pielgrzymka do grobu św. Ewliji Konteja (Kontusia) w kontekście globalnym i lokalnym," in Tatarzy-historia i kultura. Sesja naukowa, Szreniawa, 26-27 czerwca 2009, edited by Selim Chazbijewicz (Szreniawa: Muzeum Narodowe Rolnictwa i Przemysłu Rolno-Spożywczego w Szreniawie, 2009), 20-25. 
were mentioned, among others, by such well reputed travelers as Ibn Batțūta (1304-1368/9) and Evliya Çelebi (1611-1682). Some researchers advance a hypothesis that an archetype for this could possibly be Sarı Saltı (Baba or Dede) himself, a semi-legendary Turkish dervish of the thirteenth century, especially venerated by the Bektashis. ${ }^{12}$

\section{The First Polish Visitors to Mecca?}

If the legend of Kontus is rooted in the history of the 16th century, one century later we find a more concrete document which is a description of the Islamic religion, its tenets, rituals and observations, including the pilgrimage to Mecca and details of the two Holy Cities, by a Polish author Wojciech Bobowski (ca. 1610-1675). His relation was published posthumously by Thomas Hyde in Oxford in Latin (under the author's Latinized name Albertus Bobovius) in ${ }_{1690 .}{ }^{13}$ As a young boy Bobowski was captured by the Crimean Tatars and sold to Istanbul, where he embraced Islam and, as a very clever student, received careful education. He was sent to Egypt where he eventually gained his personal freedom and came to be known under the name of Ali Ufki Bey. Later, being a connoisseur of 18 languages, he became the first dragoman (tercüman paşa) of the Ottoman Sultan Mehmet (Muhammad) IV. As a Muslim, Bobowski performed the Hajj and his detailed relation may be justly considered the first genuinely Polish description of Mecca and Medina.

Two other Polish converts to Islam, unnamed, met a Franciscan father from the Netherlands, Antonio Gonzales (1604-1683) in Egypt. They were, similarly to Bobowski, in their young age sold to Istanbul by the Crimean Tatars who captured them in one of the razzias to Poland. They grew up and then settled

12 Harry T. Norris, "Ibn Battuta on Muslims and Christians in the Crimean Peninsula," in Iran and the Caucasus, Vol. 8.1 (Leiden-Boston: E.J. Brill, 2004), 7-14, Harry T. Norris, Popular Sufism in Eastern Europe: Sufi brotherhoods and the dialogue with Christianity and 'Heterodoxy' (London \& New York: Routledge, 2006), Selim Chazbijewicz, "Elementy sufizmu w tradycji I obrzędowości Tatarów polskich," in Tatarzy—historia I kultura. Sesja naukowa, Szreniawa, 26-27 czerwca 2009, ed. by Selim Chazbijewicz (Szreniawa: Muzeum Narodowe Rolnictwa i Przemysłu Rolno-Spożywczego w Szreniawie, 2009), 11-19.

13 Wojciech Bobowski, Tractatus Alberti Bobovii Turcarum imp. Mohammedis Ivti olim interpretis primarii de Turcarum liturgia, peregrinatione Meccana, circumcisione, aegrotorum visitatione etc. [...] Edited by Thomas Hyde (Oxonii: e theatro Sheldoniano, 169o), and Agnieszka Bakalarz, Polaków odkrywanie Arabii Saudyjskiej. (Kraków: Księgarnia Akademicka, 2005), 57-63. 
for good in Egypt. Their exploits, 10 or 12 visits to Medina, apparently for commerce, are only known from the words of Father Gonzales. ${ }^{14}$

The descriptions they gave of the Islamic Holy Places are very realistic and deprived of fantastic elements customarily present in second- and third-hand stories of Arabia, widespread in Europe at that time..$^{15}$

\section{The Story of Ignacy Żagiell}

The other imaginary travel story after the legend of Kontuś emerged in a nonMuslim cultural environment of the same geographical area, where original Oriental-type traditions intermingled with a Christian Orthodox substratum and Polish predominant majority influences. This genre belongs to the socalled Polish "orientalność" or "Orientality" which was equivalent to "orientalizm" or "Orientalism" as a cultural fashion coming from Western Europe. ${ }^{16}$ In this context I would like to place the imaginary travel by Ignacy Żagiell (18261891), a Polish ophthalmologist with a peculiarly colorful biography. ${ }^{17}$ Although the text was thought for a long time to be a real travelogue, in what follows I shall argue that it was an imaginary and fictional piece of work.

The main problem is that we are not always sure which part of Żagiell's life adventures was a reality and which constituted an allegation or an overt mystification (like his princely title appearing on the title page of his book). Almost everything in his biography needs research and verification. ${ }^{18}$

14 Krzysztof Kościelniak, "Grób Mahometa według relacji Polaków uprowadzonych do Egiptu w opisie franciszkanina Antoniego Gonzalesa z 1673 roku." [The Grave of Muhammad according to the accounts by two Poles kidnapped to Egypt, as described by a Franciscan Antoni Gonzales in the year 1673.], in Przeglad Orientalistyczny, nr 1-2 (212-213) 2005, 79-85, and Agnieszka Bakalarz, Polaków odkrywanie Arabii Saudyjskiej (Kraków: Księgarnia Akademicka, 2005), 57-63.

15 See below, the legend of the Muhammad's sarcophagus, hanging in the air.

16 Bogusław R. Zagórski, “Orientalizm lub orientalność polskiej wspólnoty etnicznej i politycznej w aspekcie europejskim," in Rzeczpospolita wielokulturowa-dobrodziejstwo czy obciażenie? ed. by Jerzy Kłoczowski (Warszawa: Collegium Civitas and Polski Komitet do Spraw UNESCO, 2009), 37-50.

17 Ignacy Żagiell, Podróż historyczna po Abissynii, Adel, Szoa, Nubii, uźródet Nilu, z opisaniem jego wodospadów, oraz po krajach podrównikowych, do Mekki i Medyny, Syryi i Palestyny, Konstantynopolu i po Archipelagu, przez D-ra Ig. Księcia Żagiella ... z dodaniem matego stowniczka najużywańszych wyrazów arabskich (Wilno: Nakładem autora, Drukiem Józefa Zawadzkiego, 1884).

18 Janusz Tazbir, "Wawrzeniecki i Żagiell jako twórcy falsyfikatów," in Nauka, 3 (2006), 45- 
Żagiell was born near the city of Wilno (Lithuanian: Vilnius), the capital of the Grand Duchy of Lithuania, at that time occupied by the Russian Empire. In 1850 he graduated from the Faculty of Medicine in Kiev (today Kyiv, the capital city of Ukraine), and later also studied at the Sorbonne in Paris and in Oxford. In 1859 he entered the British colonial service in India, but did not stay there long and moved to Egypt, where he worked for Ḥalìm Pasha, a son of Muhammad (Mehmet) 'Alī Pasha of Egypt, and a younger brother of Sa īd Pasha, the viceroy of Egypt.

In his capacity as a court physician Żagiell accompanied prince Halīm Pasha on an expedition to Ethiopia and the Sudan, during which the prince decided to make a little detour and to perform the Hajj. ${ }^{19}$ The expedition started from Cairo reaching Suez on October 25, 1863. There the members of the expedition carried out historical and natural investigations until they boarded a ship called el-Masr (referring to Cairo in Arabic) on November $20 .^{20}$

On April 1, 1864, the expedition arrived at Jambo [Yanbu'] where they decided to stay and rest for several days. This date is very important for two reasons. Firstly, it is unclear why the travel between Suez and Yanbu', even with several stops on the way, could last that long-over 4 months - in geographical areas where there is obviously not so much to see. Secondly, April 1 of that year coincided with Shawwāl 23, 1280, five weeks ahead of the beginning of the month of the Hajj.

After that, they finally reached Jeddah, the port city of Mecca, the latter lying at a distance of ca. $70 \mathrm{~km}$ to the east. Here Żagiell devoted a lively excursus to the description of the city, especially to its logistic and economic role in the movement of pilgrims coming to Mecca, and also of the Biblical Eve's tomb in the vicinity of the town. He informs us that Muslims, called Rygial-el-Nebi [Rijāl al-Nabī], are followers of Muhammad, to whom also adhered the dervishes and skakuns(?), a sect of Jewish origin. On the other hand, Persians and numerous branches of other Muslims are followers of 'Alī, the Prophet Muhammad's sonin-law. ${ }^{21}$

53, Jan Reychman, Podróżnicy polscy na Bliskim Wschodzie w XIX w. (Warszawa: "Wiedza Powszechna," 1972), Marek M. Dziekan, Polacy a świat arabski. Stownik biograficzny, 98 (Gdańsk: Niezależne Wydawnictwo "Rocznik Tatarów Polskich," 1998), Jerzy S. Łątka, Stownik Polaków w Imperium Osmańskim i Republice Turcji, 368 (Kraków: Księgarnia Akademicka, 2005).

19 The relation of the travel from Cairo to Mecca and Medina and visits to the two Holy Cities of Islam occupies chapters I-III, on pp. 11-53, of Dr. Żagiell's book.

$20 \quad$ Żagiell, Podróż, 13.

21 Żagiell, Podróż, 17-19. 
In Jeddah Ḥalīm Pasha invited Żagiell to accompany him on a pilgrimage to Mecca and, in order to facilitate that undertaking, to pretend to be a Muslim. Żagiell took a one-day lesson of Muslim prayers under the guidance of RamisBey [Ramīz], the adjutant of the prince; Prince Halīm was perfectly satisfied with his doctor's performance. Then they set out on the trip. ${ }^{22}$

The journey lasted two days and on the second day, at 4 p.m., the travelers arrived at the gate of Mecca named Boab-el Nebi (Bāb al-Nabī, the Gate of the Prophet). Canon fires greeted the prince, who, accompanied by the Grand Sharif of Mecca and with his whole cortège, marched towards the great mosque, named Dzami-el Nebi (Jāmic al-Nabī, Prophet's Mosque). They prayed one hour under the guidance of the Sharif in that temple built of marble, all gilded and with a mosaic on the ceiling. After the prayers they proceeded to a meal served at the palace of the Grand Sharif, where they had a dinner composed of 28 Arabian dishes, with accompaniment of Arabian music and chants. $^{23}$

Another excursus is devoted to the explanation of the meaning of the Hajj for the Holy City of Mecca, including indications coming from the Islamic Holy Script named "dzarniussahi" [al-Jāmic al-Șaḥ̄h], and some general information about the Islamic rituals. Among others, Żagiell mentioned the preaching "kilbet" (khutba, probably contaminated here with qibla), pronounced in the mosque every Friday. One of the indications seemingly contained in the khutba is that every Muslim has an obligation sine qua non to "kill any unbeliever who would dare to present himself in or around Mecca within a diameter of $7 \mathrm{~km} .{ }^{24}$ After the long preaching the mullā stepped down from the elevation raised in the great mosque of the Prophet and washed himself in the well called Zem$\mathrm{Zem}$, in which he was followed by all his listeners. ${ }^{25}$

Żagiell maintained that it was customary that on the May 27, every year, ${ }^{26}$ a caravan of pilgrims, called szewal [Shawwāl], would leave Cairo in the direction of Suez. It is a procession called mahmil, accompanying a chest with sumptuous gifts presented to Mecca by the sultan [of Turkey], the Shah of Persia, the Viceroy of Egypt, the Sultan of Morocco, the Bey of Tunis and other greater and smaller Muslim rulers of Bukhara, India etc. The chest contained two copies of

\footnotetext{
22 Żagiell, Podróż, 21-22.

23 Żagiell, Podróż, 25-26.

24 Żagiell, Podróż, 27-28.

25 Żagiell, Podróż, 29.

26 Żagiell, Podróż, 29. It is not true because the Hajj time, regulated by the Islamic hijrì calendar, is in a sort wandering around the universal calendar and each year it falls 10 days earlier.
} 
the Qurān, a kishwe [kiswah] for covering the holy monument named kaaba [al-Ka ba], presents for the Sharif of Mecca, and belongings of the chief guide of the caravan, motta El-Hadży [mullā al-hajj]. The mullā observed a rite of riding on his horse over the faithful who lay face down on the earth, tightly pressed one to another. The horse was a white purebred Arabian, walking with a soft step. However, if someone had had a limb or a rib broken on that occasion, this person would have been considered as sanctified. ${ }^{27}$

In Żagiell's understanding, all other Muslims, in imitation of the Prophet, are obliged to travel to Mecca on camelback. The pilgrims arriving in the Holy City would enter the Great Mosque, named Ret-il-Atlah (Bayt Allāh, the House of God), where they should immediately visit the Kaba. The Kaba stands in the middle of a sort of a chapel, 56 feet long, 48 wide and 80 high, in the style of beautiful Arabian architecture. It was built by Ismael, helped by Abraham and the Angel Gabriel. The latter, when the Prophet Muhammad appeared, gave him the Hadziar lasuad-eswit [al-Hajar al-Aswad, the miraculous black stone]. The stone and the chapel around it are called the Kaba. With the very secret help of the gafir [ghafïr or guard] of the mosque, Żagiell could approach the Black Stone and examine it. ${ }^{28}$

Żagiell described the Great Mosque surrounding the Kaba as a square building with 19 baabs (bāb, gate) that are never closed to the faithful. On entering the temple, people find themselves in a giant hall with a ceiling supported by 412 columns of marble, alabaster and granite. In the center, under the ceiling, Żagiell stated, one can observe seven splendid domes, similar to St. Peter's Dome in Rome, with 180 beautiful, old, big Damascene lamps. The procession around the Kaba, repeated 7 times, stops in all 4 corners of the temple where the senior mullā, or the "priest," recites prayers and sings "psalms" repeated after him by all participants. ${ }^{29}$

Żagiell moved to the eighth day of the Hajj, named zuldlicze [Dhū al-Hijja], when pilgrims performed several rituals in the city's vicinity, after which they returned to the city and then immediately try to leave from there. Most of the pilgrims then proceeded to Medina to visit the Prophet's grave, who died and is buried there. ${ }^{30}$

While staying in Mecca, Żagiell continued, the visitors used to go every day at 10 a.m. to the Prophet's Mosque ${ }^{31}$ where the Grand Sharif celebrated the office.

27 Żagiell, Podróż, 30.

28 Żagiell, Podróż, 32-33.

29 Żagiell, Podróż, 33, Żagiell reveals here a Christian perception of the Islamic ceremonies.

$30 \quad$ Żagiell, Podróż, 34 .

31 Żagiell, Podróż, 35: światynia proroka, or the temple of the prophet.; cf. note 8 above. 
In the evening, Żagiell portrayed that they would spend time in the accompaniment of Arabian music and a ballet of Arabian and Syrian dancing girls. ${ }^{32}$

Pilgrims would later return to Jeddah and sail aboard a ship to Yanbu' in order to go overland again from there to Medina-it is much more convenient and safe than travelling from Mecca to Medina by land. ${ }^{33}$ In Żagiell's description, the expedition left to Medina (called here El Medinet-el-Nebi [Madinat al-Nabī], the City of the Prophet) and entered the city through the gate Boabel-Nebi [Bāb al-Nabī]. After ceremonial greeting and honors given to the prince by the local garrison's commander, they directed themselves toward the great mosque, named Dzami-el-Nebi-Muhammed [Jāmic al-Nabī Muhammad].

There is in that mosque a sarcophagus of the Prophet which seemed to our author as if it were hanging in the air under a mosaic-covered ceiling. "Muslims think, and even are persuaded," he said, "that the coffin is supported in the air by the power of God." For Żagiell, it was either supported in the air by the power of God, or by two magnets, one below and one above the sarcophagus, as was related by another current version. ${ }^{34}$ As a matter of fact, the legend of the Prophet's sarcophagus miraculously suspended in the air, unknown to Muslims, was a typical medieval European perception of the Prophet's tomb. Early European visitors to the Islamic Holy Places as well as their subsequent followers firmly denied the legend and wrote about a sarcophagus normally standing on the ground. ${ }^{35}$ Żagiell's own personal observations, which he could make thanks to the services of an old warden of the mosque, indicated that the Muhammad's hanging sarcophagus was supported under the ceiling by two brass chains which were fixed to a thick, gilded metal rod, imbedded in the ceiling itself. ${ }^{36}$ From whom did he copy that information, it is hard to say.

32 Żagiell, Podróż, 35; music, chants and dancing girls seem, in the eyes of Żagiell, a customary distraction enjoyed during social gatherings and meals in Arabia. Cf. also on that subject C. Snouck Hurgronje, Mekka in the Latter Part of the 1gth Century: Daily Life, Customs and Learning: The Moslims of the East-Indian Archipelago, 307, index: singing girls (Leiden: E.J. Brill, 1970).

33 Żagiell, Podróż, 38.

34 Żagiell, Podróż, 43.

35 See, for example, F.E. Peters, Mecca: A Literary History of the Muslim Holy Land, 300301 (Princeton, New Jersey: Princeton University Press, 1994), F.E. Peters, The Hajj: The Muslim Pilgrimage to Mecca and the Holy Places, 138-143 (Princeton, New Jersey: Princeton University Press, 1994), Krzysztof Kościelniak, "Grób Mahometa według relacji Polaków uprowadzonych do Egiptu w opisie franciszkanina Antoniego Gonzalesa z 1673 roku," Przegląd Orientalistyczny, nr 1-2(212-213) (2005), 79-85, Agnieszka Bakalarz, Polaków odkrywanie Arabii Saudyjskiej. (Kraków: Księgarnia Akademicka, 2005), 76.

36 Żagiell, Podróż, 45. 
In the evening the cortège visited kajmakan (qā̄im-maqām, the commander), in his palace and spent time enjoying music, food and drink, and conversation. During the event, one of the guests, an old Pasha, questioned who exactly the doctor was with his apparent European resemblance and "not looking like a dweller of the Orient." The doctor explained he was an Egyptian, and Prince Halīm added they were old friends since their studies in Paris. A potentially dangerous incident was thus averted. ${ }^{37}$

On the next day, they took dejeuner with a rich merchant who treated them to 22 Arabian national dishes. There was no soup, but before the meal they drank a sort of anisette. After the meal, sorbets and coffee were served. ${ }^{38}$

When the cortège finally left Medina, Ramis-Bey complimented Żagiell on his performance, saying: "Congratulations, doctor, you splendidly played the role of a faithful Muslim. Today there is no more threat. I am so glad that my friend and my student successfully escaped with a whole skin from that abode of a wild fanaticism." 39

This Hajj account must have made an impact on its Polish readers during the late nineteenth and early twentieth century with its description of this Muslim ritual. A closer reading of the text reveals that it was a composition of stereotypes and remnant medieval perceptions about the Hajj and the tomb of the Prophet. Factual observations are interwoven with figments of the author's imagination.

According to Żagiell himself, he spoke French, a standard among educated people at that time, and some Turkish because of his professional position among the Ottomans. But his lack of knowledge of Arabic-especially for someone claiming (although fictitiously and in a dramatic moment) an Egyptian descent-makes his account questionable. His citations of Arabic terms or geographical names are erroneously spelled, which indicate that he mostly depended on his readings on Islam and hearsay information. Although he spent a part of his life in Arabic-speaking countries, his knowledge of Arabic is not well demonstrated in the travel account. Moreover, a dictionary of over 1,00o "most frequently used" Arabic words with their Polish equivalents, inserted by Żagiell at the end of his book, ${ }^{40}$ also testifies to his linguistic incompetence that is manifested in mixing literary and dialectal (mostly Egyptian) words, wrongly understood and interpreted expressions, and the addition

$\begin{array}{ll}37 & \text { Żagiell, Podró } \dot{z}, 46-48 . \\ 38 & \text { Żagiell, Podró } \dot{z}, 52 . \\ 39 & \text { Żagiell, Podró } \dot{z}, 53 . \\ 40 & \text { Żagiell, Podró } \dot{z}, 349-258 .\end{array}$




\section{PODRÓZ HISTORYCZNA \\ P 0}

\section{ABISSINII}

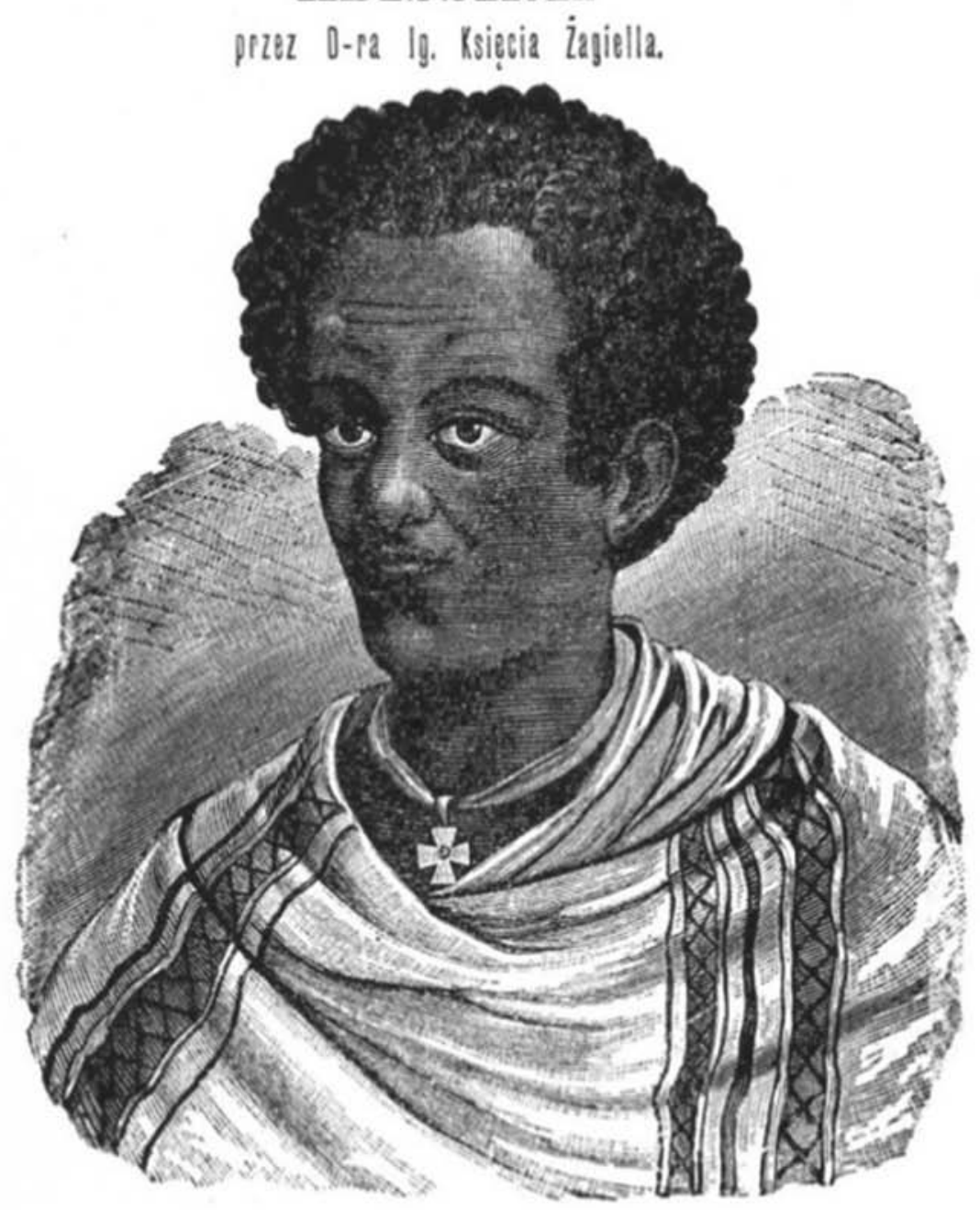

Negus Sahle-Sallasi Król Szoa.

W I L N 0.

Druklem J. Za wadzkiego.

1884.

FIGURE 6.4 The cover page of the travel book by Ignacy Żagiell AUTHOR'S COLLECTION 
of words of non-Arabic origin. It is a curiosity in itself, a collection gathered from unknown sources. ${ }^{41}$

Żagiell's fictitious portrayal of Mecca and Medina may also testify that he never travelled there and that his narrative was merely a mixture of fallacies and basic common facts. ${ }^{42}$ Therefore, the real importance of Żagiell's pilgrimage account would situate itself not in the informative values of his book, which may be contested, but in the extraordinary - for the Polish reading publicsetting in which his alleged adventures take place. ${ }^{43}$

\section{Multicultural Openness}

Żagiell's narrative apparently belonged to this segment of Polish literary creation thst was meant to open new horizons to the Polish reading audience of such litrary genres and inscribed itself in romantic travel writing. On the other hand, it would give new impetus to global civilizational partnership, in which occupied Poland was so late, and when civilization still seemed to be a future blessing for humanity. ${ }^{4}$

Poles, escaping from under the oppression of three occupying powers, dispersed all around the world; and thanks to their sense of adaptability they were easily integrated in other milieus and situations. ${ }^{45}$ Reports from their adventures, in most cases fragmentarily appearing in the local press, ${ }^{46}$ were gladly

41 It is interesting to note that even if the most important part of the book is devoted to Ethiopia, there is no Ethiopian dictionary attached to it.

The Ethiopian content of the Żagiell's book was already studied, critically analyzed, and commented upon by Prof. Stanisław Chojnacki in "Dr. Żagiell's "Journey" to Abyssinia: a piece of Polish pseudo-Ethiopica," in Journal of Ethiopian Studies 2/1 (1964): 25-32, reprinted in Polish as: "Podróż dr. Żagiella do Abisynii," in Przegląd Orientalistyczny 4/56 (1965): 355-359. The conclusion of Chojnacki's verification and analyses was critical for Żagiell and his veracity, but this mystification—as Chojnacki openly calls it—lasted undisclosed almost 100 years when it was treated by readers as a true story.

Stanisław Burkot, Polskie podróżopisarstwo romantyczne (Warszawa: Państwowe Wydawnictwo Naukowe, 1988), 99.

44 Helena Zaworska, Sztuka podróżowania. Poetyckie mity podróży (Kraków: Wydawnictwo Literackie, 1980), 41.

45 Marek M. Dziekan, Polacya świat arabski. Stownikbiograficzny (Gdańsk:Niezależne Wydawnictwo "Rocznik Tatarów Polskich," 1998). Jerzy S. Łątka, Stownik Polaków w Imperium Osmańskim i Republice Turcji (Kraków: Księgarnia Akademicka, 2005), Jan Reychman, Podróżnicy polscy na Bliskim Wschodzie w XIX w. Warszawa: “Wiedza Powszechna," 1972.

46 Apart of Żagiell's book, few other relations appeared in the 19th century in their com- 
read in the home country where they brought a desired breath of fresh air and a feeling of free human space and open possibilities. For this reason, Żagiell's work probably belonged to this genre of describing unusual lands and cultures of Asia, Africa, Australia and the Americas.

During the time of Żagiell's publication, a new form of Polish Orientality and Orientalism appeared. In 1858, in Warsaw, which was together with Wilno under the same Russian occupation, a Polish translation of the Holy Qurān first appeared in print. It was attributed to a certain Polish Tatar named Jan Murza Tarak Buczacki, who allegedly prepared his translation directly from Arabic. The authorship of the translation was another mystery that lasted over 100 years and was only recently disclosed on the basis of a thorough analysis of newly found historical and literary evidence. ${ }^{47}$ Such publications reinforced a common knowledge about the Polish Tatars, a tiny ethnographic group of strong patriotic feeling. Other works from the same period included a Polish translation of the biography of the Prophet Muhammad (1850 $)^{48}$ by the American author Washington Irving (1783-1859). ${ }^{49}$ In 1875 Ármin Vámbèry (1832-1913), a Hungarian Turcologist and traveler, published a book titled Islam in the rgth Century, which gained wide popularity in Europe thanks to its highly

plete forms; see for example relations of travels to the Middle East by Edward Raczyński (1786-1845), an aristocrat, politician, lover of travels and protector of arts, founder of a great public library in the city of Poznań: Dziennik podróży do Turcyi odbytey $w$ roku 1814 (Wrocław: W.B. Korn, 1823), and by Maurycy Mann (1814-1876), writer, journalist and politician: Podróż na Wschód. T. 1-3 (Kraków: nakładem I czcionkami drukarni "Czasu," 1854-1855). Other exploits in the Orient, earlier known from fragmentary publications or just from a hearsay, were published in independent Poland, for example those by Władysław Jabłonowski (1841-1894), doctor of medicine, ethnographer, colonel and coorganizer of Ottoman sanitary services, author of Pamiętniki z lat 1851-1893 (wybór), ed. by Józef Fijałek (Wrocław-Warszawa-Kraków: Zakład Narodowy imienia Ossolińskich, 1967) and Zygmunt Miłkowski, alias Teodor Tomasz Jeż (1824-1915), émmigré politician, diplomat and prolific writer, author of Od kolebki przez życie: wspomnienia, т. 1-3, ed. by Adam Lewak (Kraków: Polska Akademja Umiejętności, 1936-1937).

The text was not translated from the original Arabic by a Tatar author, as it was claimed on the title page, but by a group of Polish literati from Wilno and was based (including footnotes) on the French translation by Claude-Étienne Savary (1750-1788); see Joanna Kulwicka-Kamińska, "Koran po polsku," PAL Przegląd Artystyczno-Literacki, nr 10 (1998), 15-29, and Czesław Łapicz, "Niezwykłe losy pierwszego drukowanego przekładu Koranu na język polski," Studia Polonistyczne. Seria Językoznawcza. T. 20, z. 2 (2013), 129-143.

48 Washington Irving, Life of Mahomet (London: H.G. Bohn, 1850, and Leipzig: Bernh. Tauchnitz jun., 1850).

49 Washington Irving, Życie Mahometa (Warszawa: Nakładem Aleksandra Nowoleckiego, 1858). 

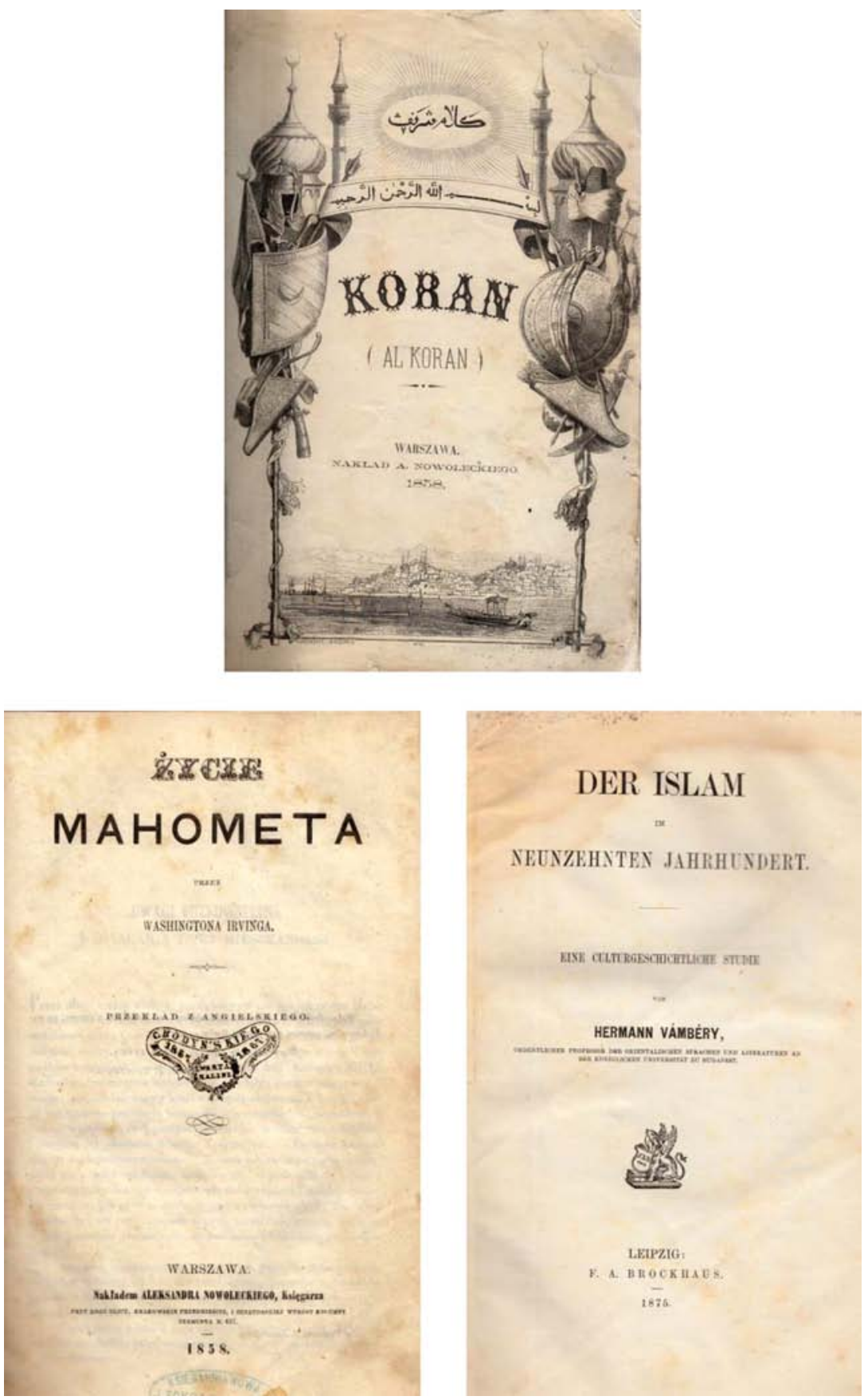

FIGURE 6.5 Various Polish Translations of Islamic sources AUTHOR'S COLLECTION 


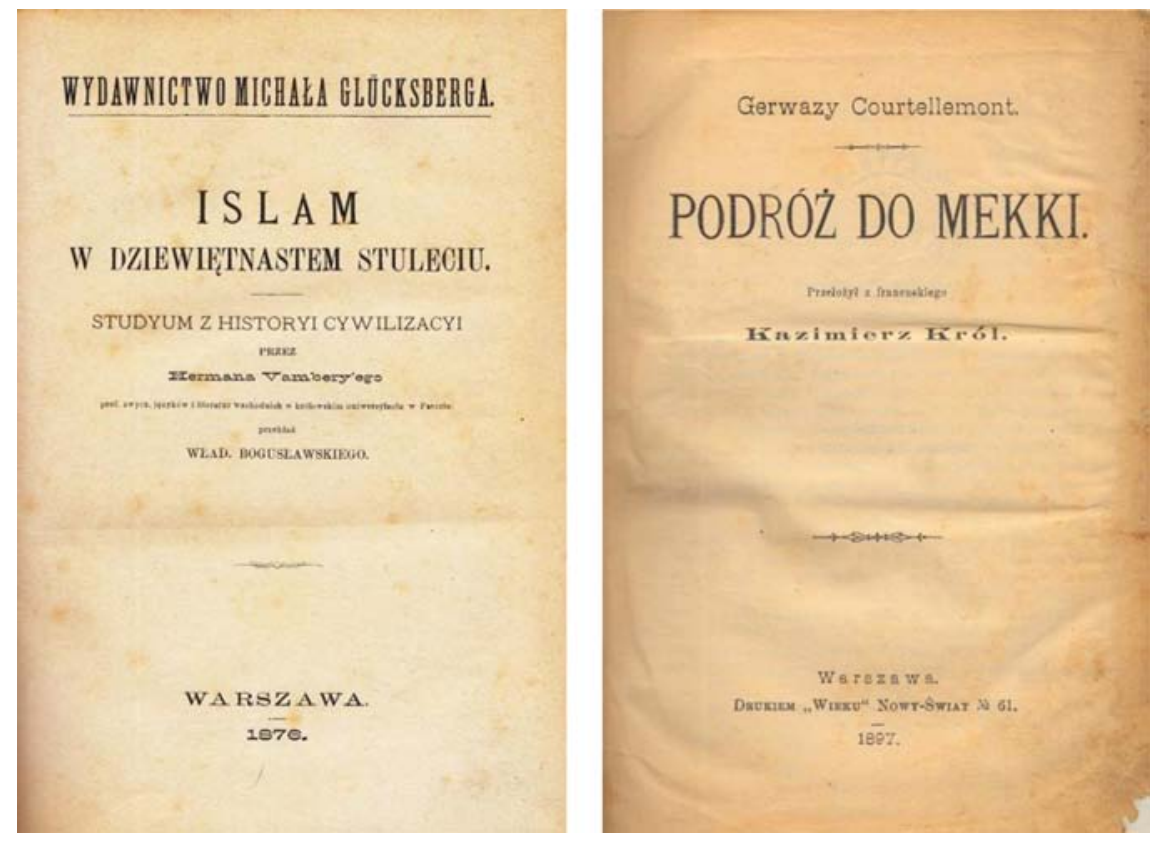

FIGURE 6.6 Polish translations of Islamic sources AUTHOR'S COLLECTION

professional and popularizing value..$^{50}$ Only a year later the book was published in Poland. ${ }^{51}$ Moreover Gervais-Courtellemont's Hajj travel ${ }^{52}$ (see chapter 4) found its ways to Polish private libraries and a Polish (although abbreviated) translation was already printed in the next year. ${ }^{53}$ These publications indicate certain demands of the local book market for publications on Islamic religion, history and culture, and even more widely disseminating and deeply imbibing in the common knowledge such notions as Arabia and Mecca.

Among the simple countryside population of Muslims living in Eastern Poland, and on the level of the educated reading strata of the Polish-language community, the effect of different (comparatively widely known although not

50 Ármin Vámbèry, Der Islam in neunzehnten Jahrhundert. Eine culturgeschichtliche Studie (Leipzig: F.A. Brockhaus, 1875).

$5^{1}$ Ármin Vámbèry, Islam w dziewiętnastem stuleciu. Studium z historyicywilizacyi (Warszawa: Wydawnictwo Michała Glücksberga, 1876).

52 Jules-Claudin Gervais-Courtellemont, Mon voyage à la Mecque (Paris: Librairie Hachette et $\left.\mathrm{C}^{\mathrm{ie}}, 1896\right)$.

53 Jules-Claudin Gervais-Courtellemont, Podróż do Mekki, transl. from French by Kazimierz Król (Warszawa: Drukiem “Wieku,” 1897). 
numerous) Hajj relations was synchronous and created a positive synergy. It conjured up a feeling of multicultural togetherness and produced a certain state of mind which accepted the Polish-Middle Eastern relations as something natural and friendly, on a par and not in adversity.

\section{In the 2oth Century}

The story of Polish Hajj does not end here; it has only just begun. In the twentieth century Leopold Weiss (1900-1992), a Polish Jew from the city of Lwów $^{54}$ who was a Muslim convert, made a remarkable account of his road to Islam and his Hajj under the newly adopted name of Muhammad Asad. ${ }^{55}$

In 1913, a certain wealthy Tatar Aleksander Illasewicz from Kowno (today Kaunas in Lithuania) went on Hajj and apparently repeated the sad experience of Łowczycki. His money was stolen and he suffered heavily during the Hajj and on the way back home. During the trip he made notes on the margins of two handwritten prayer books which he was carrying with him all the time, indicating the dates of his movements and other activities and registering names of all significant persons he met. The manuscripts were lost during the war. ${ }^{56}$

In 1930, the first Polish Mufti, Dr. Jakub Szynkiewicz (1884-1966), ${ }^{57}$ performed the Hajj to Mecca and left an important description of it. A few frag-

54 At that time, under the Austrian occupation, the city was called Lemberg in German, now it is L'viv in Ukraine, also known under its Russian name L'vov.

55 Muhammad Asad, The Road to Mecca. ([New York]: Simon and Schuster, 1954). For Asad's connection with Poland, see Bogusław R. Zagórski, "Leopold Weiss or Muhammad Asad and His Polish Cultural Background" (paper presented at the international symposium "Mohammad Asad-A Life for Dialogue," King Faisal Center for Research and Islamic Studies, Riyadh, April 11-12, 2011). Asad had in fact a strong Polish cultural background, achieved in younger years through daily life in a Polish environment and a Polish school, where he admired Polish classical literature. He spoke Polish until the end of his days, but attention and the life story of this one of the most influential Muslim intellectuals and politicians of the 2oth century was not concentrated on Poland and Polish matters any more.

56 Agnieszka Bakalarz, Polaków odkrywanie Arabii Saudyjskiej (Kraków: Księgarnia Akademicka, 2005), 42-43.

57 Jakub Szynkiewicz (1884-1966) was born in a middle class Tatar family in Western Belarus (of today), studied in St.-Petersburg, first in the Institute of Technology, and then at the Department of Oriental Languages of St.-Petersburg University. In World War I he served in the Russian army, and from 1918-1919 took part in the national struggle of the 


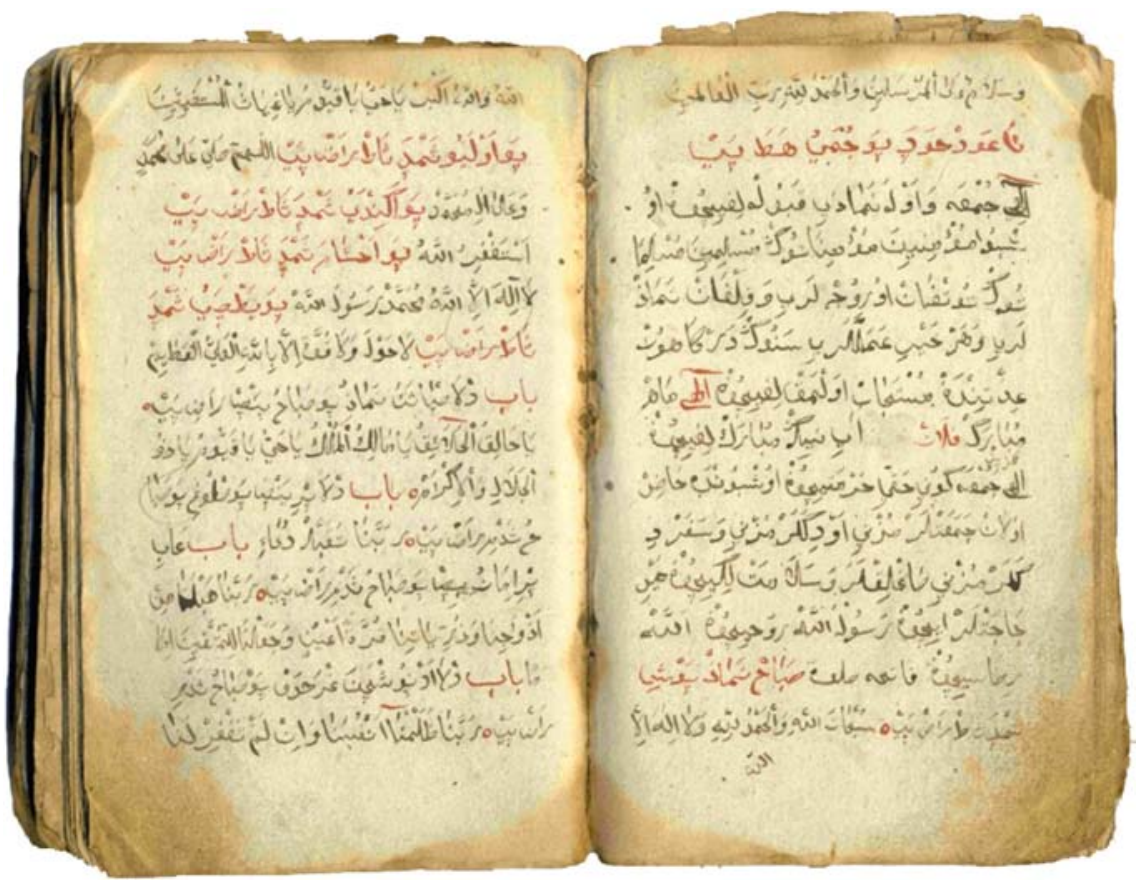

FIGURE 6.7 A Polish-Tatar handwritten prayer book from the 19th $c$. AUTHOR'S COLLECTION

ments of the Mufti's Arabian travel were printed in the magazine Życie Tatarskie (Tatar Life) in 1934-1935. A collection of the Mufti's various travels has been recently published by Grzegorz Czerniejewski in 2013.58

Crimean Tatars for independence. After his return to Poland, and with the support of the Polish government, he continued his Oriental studies at the University of Berlin where he obtained his Ph.D. diploma for a dissertation on the Turkish syntax in 1925. In December of the same year, at the All-Polish Congregation of Muslim Communities, he was elected for the post of the Mufti. Under the Germans in World War II, he was nominated in 1941 the Mufti of Ostland (occupied territories of Eastern Poland, Belarus and Lithuania). In 1944 he was evacuated to Vienna and then settled in Egypt where he lived until 1952. After the revolution lead by Jamāl 'Abd an-Nāșir he finally moved to the usA and lived there until the end of his days, always retaining the formal title of the Mufti of Poland.

$5^{8}$ Only very recently did the personal narrative of the Hajj performed by Dr. Szynkiewicz appear in print; see Grzegorz Czerwiński, Sprawozdania z podróży Muftiego Jakuba Szynkiewicza.Źródta, omówienie, interpretacja (Białystok: Książnica Podlaska, 2013), 84-114; see also Marek M. Dziekan, Polacy a świat arabski. Stownik biograficzny (Gdańsk: Niezależne Wydawnictwo "Rocznik Tatarów Polskich," 1998), 88-89. 


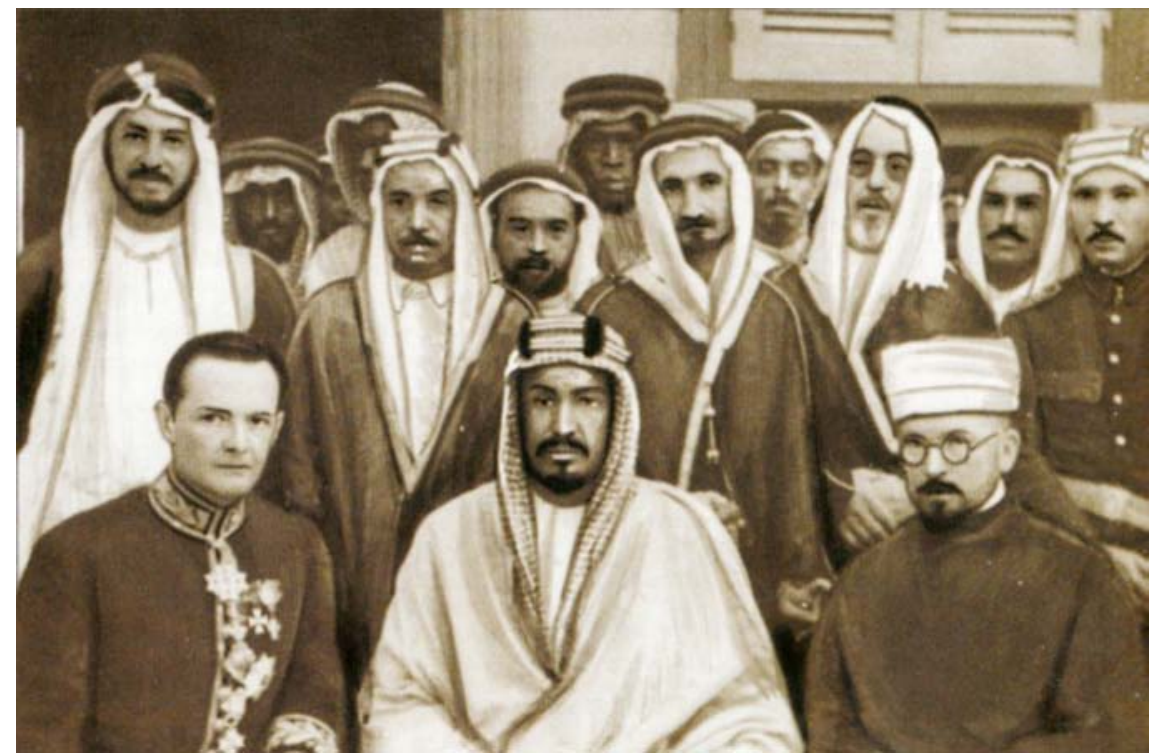

FIGURE 6.8 The Mufti of Poland, Dr.Jakub Szynkiewicz (sitting, first from the right) with King 'Abd al-'Aziz (in the centre), Count Raczyński (on the left) and Saudi officials (standing) in Jeddah, May 1930 AUTHOR'S COLLECTION

The Mufti's Hajj trip was part of a Polish diplomatic delegation. His trip represented the beginning of quite another story of the interwar times, when Poland regained independence after 135 years of partitions on November 11, 1918. On March 11, 1930 the Polish government officially recognized independence of the Saudi Kingdom of Hijāz and Najd and it was decided to convey this information to the Saudi ruler directly. An official Polish delegation led by Count Raczyński, ${ }^{59}$ in which the mufti participated, first came to Egypt and then travelled from Suez to Jeddah aboard a ship. In May 1930 they met twice with the King, Count Raczyński presented his credentials and a letter from the President of Poland, Ignacy Mościcki, officially recognizing the Kingdom.

The address by Count Raczyński was representative of the romantic style of thinking and the positive emotional approach to the Muslim World that were quite common in Poland at that time:

59 Edward Bernard Raczyński (1891-1993), deputy head of the Eastern Division of the Ministry of Foreign Affairs in Warsaw, and later on, an ambassador, a Foreign Minister, and finally the President of the Polish Government in Exile in London during World War II. 
Poland well knows and admires the chivalrous Arab nation, world famous for its heroism and fondness of freedom, for years acclaimed by the greatest Polish poets [...] It is with the greatest pleasure in expressing the feelings of understanding and sympathy extended by the Polish nation towards the Arab nation that I have the privilege to speak to Your Majesty [...] Fame is spreading the name of Your Majesty wider and wider among your co-religionists, as being that of a ruler who is particularly pious and observant of the faith, and this sounds a loud echo among the Polish Muslims who settled in the far north centuries ago [...] Today, Great Mufti Jakub Szynkiewicz, the eminent religious leader, comes here with me on behalf of the Muslims of Poland in order to renew personal links with the founder of their religion and to greet Your Majesty as the one, who holds the eminent position of the ruler and defender of the holy places of Islam. ${ }^{60}$

The Polish delegation presented to the king several gifts, among which there was a handwritten copy of the Qur'ann from the 18th century, produced in the milieu of the Polish-Lithuanian Tatars, and an album with photographs of the Polish mosques. The gifts were gladly received by the King, who showed vivid interest in the situation of Muslims in Poland and wished them success in preserving the Islamic faith. ${ }^{61}$

After the official meeting, the Mufti left for Mecca to take part in the rituals of the pilgrimage which were to start only a couple of days later. He performed the 'Umra first and with the other pilgrims waited for the Hajj. In the meantime he visited remarkable places in Mecca and made observations on the poor condition of the city, its buildings and organization of urban services. While performing the Hajj, the Mufti attracted malaria which developed later on when he was already on a Ziyāra in Medina. That was a misfortune

6o Cited after Andrzej Kapiszewski, "The establishment of Polish-Saudi Relations: Count Raczyński's Visit to King Abdulaziz in 1930 and Prince Faisal's Visit to Warsaw in 1932," in Saudi Prince in Warsaw. A Milestone in the Relationship Between Poland and Saudi Arabia. A seminar to commemorate the 7oth anniversary of the visit of His Royal Highness Prince Faisal Ibn Abdulaziz Al-Saud to Poland in May 1932. May 22, 2002 (Warsaw: Warsaw University Library, 2002), 9-10; Polish version of the address as cited by Jakub Szynkiewicz in his relation, see Grzegorz Czerwiński, Sprawozdania z podróży Muftiego Jakuba Szynkiewicza. Źródta, omówienie, interpretacja (Białystok: Książnica Podlaska, 2013), 89-9o; on the Hajj by Mufti Szynkiewicz, see also Agnieszka Bakalarz, Polaków odkrywanie Arabii Saudyjskiej (Kraków: Księgarnia Akademicka, 2005), 44-50.

61 Kapiszewski, “The establishment," 11; Czerniejewski, Sprawozdania, 91. 
because the sickness kept him in bed for two weeks, after which he only had two remaining days to visit the Mosque of the Prophet and other places of interest. ${ }^{62}$

The most shocking observation he made was that of a Soviet delegation to the Hajj, moving around in a car with a great red flag. It gave Szynkiewicz an occasion to reflect on what he saw as the "hypocrisy" of the communist propaganda in the Muslim world and on the mysterious silence of the locals when he had asked about such an unexpected encounter in Arabia. ${ }^{63}$ Seemingly it had something to do with the rumors spread that Muslim representatives were to meet in Mecca on the occasion of the Hajj to discuss the Palestinian question. Soviet authorities probably sent their representatives to keep an eye on the situation.

A particularly sad experience was the Mufti's visit to a slave market in Mecca which deeply moved his feelings. The slaves were men, women, elderly people and children, almost exclusively Sudanese. The price for a slave was at that time between 80-10o English pounds. The slaves on the market showed resigned attitude, but those met in rich people's homes were quite happy. He was told that in private homes of the king and other personalities, there were numerous slave women. ${ }^{64}$

On the other hand, the Mufti underlined that despite the difficult economic situation of the young state, the King introduced very strict security measures in the country and all pilgrims could be safe from past Beduin attacks and feel at home in Mecca and Medina. ${ }^{65}$

The official Polish delegation to Arabia became the subject of several press reports in Poland of this time. The basic information about the event went into circulation and was quite widespread, reinforcing the idea of close cooperation of Polish Muslims with the government in the relations of Poland's diplomatic relations with the Middle East. ${ }^{66}$

A year after the Mufti, the imam of the Islamic community in Warsaw, Esfandiar Fazlejew, performed the Hajj, but did not leave any notes from his trip. Other information indicates that two more Muslims from Poland went to Mecca to perform the Hajj in the 1930s, but no exact detail is available. ${ }^{67}$

\footnotetext{
62 Czerniejewski, Sprawozdania, 102-104.

63 Czerniejewski, Sprawozdania, 94, 100-101.

64 Czerniejewski, Sprawozdania, 106-107.

65 Czerniejewski, Sprawozdania, 94.

66 Agnieszka Bakalarz, Polaków odkrywanie Arabii Saudyjskiej. (Kraków: Księgarnia Akademicka, 2005), 141.

67 Bakalarz, Polaków odkrywanie, 44 (with variant spellings of the imam's name).
} 
It wasn't until 1991, when the first two Poles after World War II went to perform the ${ }^{\prime} U m r a,{ }^{68}$ that a new era of Polish connections with the Hajj began.

\section{Conclusion}

East-Central Europe, a region where the Commonwealth composed of the Kingdom of Poland and the Grand Duchy of Lithuania once existed, is not a part of the core Islamic World in any sense. A tiny Muslim minority has played nevertheless an important part in the history of the last 600 years of the country. Neighboring countries in Eastern Europe, such as the Crimea, Northern Caucasus and the Volga basin, densely populated since many centuries by the Muslims, had political and cultural history different from that of the PolishLithuanian Commonwealth, even though they never maintained mutual interaction. Meccan travelers from those lands are a separate question.

Muslims in Poland as a social group were mainly countryside dwellers, occupied with agriculture, commerce and petty manufacturing. Wealthy members of that community together with the intellectual elite were quite few and only they could eventually think of covering the expenses of the fifth pillar of Islam, the Hajj. On the other hand, some Tatars were taking people who maintained commercial relations over long distances and were experienced in far-reaching travels, extending to the Ottoman Empire. These were the prerequisite conditions that would enable the Muslims from the Commonwealth going on pilgrimage. The precarious economic situation of Poland in pre-war times did not give Polish Muslims, mostly countryside dwellers, many opportunities to undertake a costly trip for the Hajj.

The Hajj was naturally known as a conditional requirement of the Islamic faith, and every Muslim was dreaming about its accomplishment. Some could perform it, and in such cases the news spread around. If the available relations are scarce, it means that the practice was limited. Satisfying that religious longing was in fact only available to the crème de crème of the small Muslim community.

However, the fascination with such exotic travel to Arabia engaged the minds of not only the Muslims. Polish literati and intellectuals had a curiosity for a mysterious, unreachable place. At the same time, practical politicians had to cope with the living reality of a close neighborhood with the Ottoman Empire, an important player in European politics and economy. Polish travelers 
to the Middle East, diplomats or traders, composed accounts of their journeys. Besides that, most important works on Turkey were translated from Western European languages (mainly from French and German, rarely from other languages). These translated works helped to create a certain level of familiarity with Islamic culture. The Hajj, as a ritual, was not completely unknown among the majority of Polish society. Initially perceived as a far-reaching journey, an exotic Oriental endeavor, it became in interwar period a useful tool of diplomacy in the Weltpolitik. The mufti and his Hajj, his personal religious act, finally was used-with the Mufti's apparent consent-as a suitable tool of national diplomacy and an important element of the formal image of Poland, which the Foreign Ministry wanted to present to Middle Eastern countries. The legend of Kontuś and Dr. Żagiell's fabrications found an unexpected continuation.

\section{Bibliography}

Asad, Muhammad. The Road to Mecca. [New York]: Simon and Schuster, 1954.

Bakalarz, Agnieszka. Polaków odkrywanie Arabii Saudyjskiej. [Poles Discovering Saudi Arabia]. Kraków: Księgarnia Akademicka, 2005.

[Bobowski, Wojciech]. Tractatus Alberti Bobovii Turcarum imp. Mohammedis Ivti olim interpretis primarii de Turcarum liturgia, peregrinatione Meccana, circumcisione, aegrotorum visitatione etc. [...] Edited by Thomas Hyde. Oxonii: e theatro Sheldoniano, 1690.

Borawski, Piotr. Tatarzy w dawnej Rzeczypospolitej. [Tatars in Old Commonwealth]. Warszawa: Ludowa Spółdzielnia Wydawnicza, 1986.

Borawski, Piotr and Aleksander Dubiński. Tatarzy polscy. Dzieje, obrzędy, legendy, tradycje [Polish Tatars: History, Rituals, Legends, Traditions]. Warszawa: Iskry, 1986.

Burkot, Stanisław. Polskie podróżopisarstwo romantyczne [Polish Romantic Travel Writing]. Warszawa: Państwowe Wydawnictwo Naukowe, 1988.

Chazbijewicz, Selim. "Elementy sufizmu w tradycji i obrzędowości Tatarów polskich" ["Elements of Sufism in the Tradition and Ritual of the Polish Tatars"]. In Tatarzyhistoria i kultura. Sesja naukowa, Szreniawa, 26-27 czerwca 2009 [Tatars-History and Culture. Scientific Session, Szreniawa, 26-27 June 2009]. Edited by Selim Chazbijewicz. Szreniawa: Muzeum Narodowe Rolnictwa i Przemysłu Rolno-Spożywczego w Szreniawie, 2009. 11-19.

Chojnacki, Stanisław. "Dr. Żagiell's "Journey" to Abyssinia: a piece of Polish pseudoEthiopica," in Journal of Ethiopian Studies, 2.1 (1964): 25-32.

Chojnacki, Stanisław. “'Podróż' dr. Żagiella do Abisynii” [The ‘Travel' of Dr. Żagiell to Abyssinia], in Przeglad Orientalistyczny, 4.56 (1965): 355-359. 
Czerwiński, Grzegorz. Sprawozdania z podróży Muftiego Jakuba Szynkiewicza. Źródta, omówienie, interpretacja [The Mufti Jakub Szynkiewicz's Reports from His Travels. Sources, Discussion, Interpretation]. Białystok: Książnica Podlaska, 2013.

Dubiński, Aleksander. “Une légende des Tatars de Pologne." In Quand le cribleétaitdans la paille: hommage à PertevNailiBoratav, edited by RémyDor and Michèle Nicolas. Paris: G.-P. Maisonneuve et Larose, 1978. 169-175.

Dziekan, Marek M. Polacy a świat arabski. Stownik biograficzny [Poles and the Arab World: A Biographical Dictionary]. Gdańsk: Niezależne Wydawnictwo "Rocznik Tatarów Polskich," 1998.

Gervais-Courtellemont, [Jules-Claudin]. Mon voyage à la Mecque. Paris: Librairie Hachette et $\mathrm{C}^{\mathrm{ie}}, 1896$.

Gervais-Courtellemont, Jules-Claudin (printed: GerwazyCourtellemont). Podróż do Mekki [A Travel to Mecca]. Przełożył z francuskiego [Translated from French by] Kazimierz Król. Warszawa: Drukiem "Wieku," 1897.

Gökbilgin, M. Tayyip. Lehistan Tatarları hakkında bir risale "Risale-i Tatar-ı Leh”. İstanbul, 1971.

Górak-Sosnowska, Katarzyna, ed. Muslims in Poland and Eastern Europe: Widening the European Discourse on Islam. Warszawa: University of Warsaw, Faculty of Oriental Studies, 2011.

Grygajtis, Krzysztof. "Obraz Tatarszczyzny litewskiej na dworze tureckim w połowie XVI wieku" ["Image of the Lithuanian Tatar world at the Turkish court in the middle of the 16th c."]. In Studia z dziejów nowożytnych. Wrocław 1988. Acta Universitatis Wratislaviensis, nr 1059, "Historia," nr 71. 25-40.

Hurgronje, C. Snouck. Mekka in the Latter Part of the 19th Century: Daily Life, Customs and Learning: The Moslims of the East-Indian Archipelago. Translated by J.H. Monahan. Leiden: E.J. Brill, 1970 (photomechanical reprint of the ed. 1931).

Irving, Washington. Life of Mahomet. London: H.G. Bohn, 1850 (also Leipzig: Bernh. Tauchnitz jun., 1850).

Irving, Washington. ŻycieMahometa. [Muhammad's Life.] Warszawa: Nakładem Aleksandra Nowoleckiego, 1858 .

Jabłonowski, Władysław. Pamiętniki z lat 1851-1893 (wybór). [Memoirs from the Years 1851-1893 (selection)]. Edited by Józef Fijałek. Wrocław-Warszawa-Kraków: Zakład Narodowy imienia Ossolińskich, 1967.

Kapiszewski, Andrzej. "Stosunki polsko-saudyjskie w okresie międzywojennym." [Polish-Saudi relations in interwar period]. In Przeglad Orientalistyczny, nr 1/2 (96/97), 2001: $45^{-52}$.

Kapiszewski, Andrzej. "The establishment of Polish-Saudi Relations: Count Raczyński's Visit to King Abdulaziz in 1930 and Prince Faisal's Visit to Warsaw in 1932." In Saudi Prince in Warsaw. A Milestone in the Relationship Between Poland and Saudi Arabia. A seminar to commemorate the 7oth anniversary of the visit of His Royal Highness Prince 
Faisal Ibn Abdulaziz Al-Saud to Poland in May 1932. May 22, 2002. Warsaw: Warsaw University Library, 2002. 8-14.

Kościelniak, Krzysztof. “Grób Mahometa według relacji Polaków uprowadzonych do Egiptu w opisie franciszkanina Antoniego Gonzalesa z 1673 roku” [The Grave of Muhammad according to the accounts by two Poles kidnapped to Egypt, as described by a Franciscan Antoni Gonzales in the year 1673]. In Przeglad Orientalistyczny, nr 1-2(212-213) 2005: 79-85.

Kulwicka-Kamińska, Joanna. "Koran po polsku" [Qurān in Polish]. In PAL Przegląd Artystyczno-Literacki, nr 10, 1998: 15-29.

Łapicz, Czesław. "Niezwykłe losy pierwszego drukowanego przekładu Koranu na język polski" [Extraordinary stories of the first printed translation of the Qurān into Polish]. In Studia Polonistyczne. Seria Jezzykoznawcza. T. 20, z. 2, 2013: 129-143.

Łątka, Jerzy S. Stownik Polaków w Imperium Osmańskim i Republice Turcji [Dictionary of Poles in the Ottoman Empire and in the Turkish Republic]. Kraków: Księgarnia Akademicka, 2005 .

Majda, Tadeusz. "Turkish-Byelorussian-Polish Handbook." In Rocznik Orientalistyczny, Vol. XLIX, No. 2, 1994: 139-158.

Mann, Maurycy. Podróż na Wschód [A Travel to the Orient]. T. 1-3. Kraków: nakładem i czcionkami drukarni "Czasu," 1854-1855.

Miłkowski, Zygmunt (alias Teodor Tomasz Jeż). Od kolebki przez życie: wspomnienia. [From the CraddleThrough the Life: Memoirs]. T. 1-3. Edited by Adam Lewak. Kraków: Polska Akademja Umiejętności, 1936-1937.

Miśkiewicz, Ali: Tatarzy polscy 1918-1939. Życie spoteczno-kulturalne i religijne [Polish Tatars 1918-1939: Socio-cultural and Religious Life]. Warszawa: Państwowe Wydawnictwo Naukowe, 1990.

Muchliński, A. ed., [Risāleh-i Tātār-i Leh] / Zdanie sprawyy o Tatarach litewskich, przez jednego z tych Tatarów złożone Suttanowi Sulejmanowi w roku 1558. Z języka tureckiego przetożyt, objaśnit i materiatami historycznemi uzupetnit [...]. Z dotaczeniem tekstu tureckiego [An account of the Lithuanian Tatars, which by one of those Tatars was submitted to the Sultan Süleyman in the year 1558. Translated from Turkish, explained and amplified with historical materials by ... With the Turkish text annexed]. (OddrukTekiWileńskiej), [Wilno], 1858.

Norris, Harry T., "Ibn Battuta on Muslims and Christians in the Crimean Peninsula." In Iran and the Caucasus, Vol. 8.1. Leiden-Boston: E.J. Brill, 2004. 7-14.

Norris, Harry T. Popular Sufism in Eastern Europe: Sufi brotherhoods and the dialogue with Christianity and 'Heterodoxy'. London \& New York: Routledge, 2006.

Norris, Harry T. Islam in the Baltic: Europe's Early Muslim Community. London-New York: Tauris Academic Studies, an imprint of I.B. Tauris Publishers, 2009. (International Library of Historical Studies 53).

Nosowski, Jerzy. Polska literatura polemiczno-antyislamistyczna XVI, XVII i XVIII $w$. 
Wybór tekstów i komentarze [Polish polemic-anti-Islamic literature of the 16 th, $17^{\text {th }}$ and 18 th centuries. Selection of texts with commentaries]. 1-2. Akademia teologii katolickiej, Warszawa 1974.

Peters, F.E. The Hajj: The Muslim Pilgrimage to Mecca and the Holy Places. Princeton, New Jersey: Princeton University Press, 1994.

Peters, F.E. Mecca: A Literary History of the Muslim Holy Land. Princeton, New Jersey: Princeton University Press, 1994.

Połczyński, Michael. "Seljuks on the Baltic: Polish-Lithuanian Muslim Pilgrims in the Court of Ottoman Sultan Süleyman I." In Journal of Early Modern History, 19, 2015: $1-29$.

Porter, Venetia, ed. Hajj: Journey to the Heart of Islam. Cambridge, Massachusetts: Harvard University Press, 2012.

Raczyński, Edward. Dziennik podróży do Turcyi odbytey w roku 1814 [A Journal of a Trip to Turkey Performed in the year 1814]. Wrocław: W.B. Korn, 1823.

Reychman, Jan. Życie polskie w Stambule w XVIII wieku [Polish life in Istanbul in the 18th century]. Warszawa: Państwowy Instytut Wydawniczy, 1959.

Reychman, Jan. Orient $w$ kulturze polskiego oświecenia [Orient in the culture of the Polish Enlightment]. Wrocław: Zakład Narodowy im. Ossolińskich, 1964.

Reychman, Jan. Podróżnicy polscy na Bliskim Wschodzie wXIXw [Polish travelers in the Middle East in the 19th century]. Warszawa: "Wiedza Powszechna," 1972.

Stachowski, Stanisław. Stownik historyczny turcyzmów w języku polskim [Historical dictionary of Turkish borrowings in Polish]. Kraków: Księgarnia Akademicka, 2007.

Tazbir, Janusz. "Wawrzeniecki i Żagiell jako twórcy falsyfikatów." [Marian Wawrzeniecki and Ignacy Żagiell—authors of forgeries]. In Nauka, 3, 2006: 45-53.

Turek, Wacław Przemysław. Stownik zapożyczeń pochodzenia arabskiego w polszczyźnie [Dictionary of Arabic borrowings in Polish]. Kraków: Towarzystwo Autorów i Wydawców Prac Naukowych “Universitas," 2001.

Tyszkiewicz, Jan: Tatarzy na Litwie i w Polsce. Studia z dziejów XIII-XVIII w [Tatars in Lithuania and in Poland: Studies in the History of the 13th and 18th c.]. Warszawa: Państwowe Wydawnictwo Naukowe, 1989.

Tyszkiewicz, Jan. Z historii Tatarów polskich 1794-1944 [From the History of the Polish Tatars, 1794-1944.] Pułtusk: Wyższa Szkoła Humanistyczna im. A. Gieysztora, 2002² Vámbèry, Ármin (printed: Hermann Vambery). Der Islam in neunzehnten Jahrhundert. Eine culturgeschichtliche Studie. Leipzig: F.A. Brockhaus, 1875.

Vámbèry, Ármin (printed: Herman Vambery). Islam w dziewiętnastem stuleciu. Studium z historyi cywilizacyi [Islam in the 19th century. A study in the history of civilization]. Warszawa: Wydawnictwo Michała Glücksberga, 1876.

Vorbrich, Ryszard. "Pielgrzymka do grobu św. Ewliji Konteja (Kontusia) w kontekście globalnym i lokalnym" ["A Pilgrimage to the Grave of Holy EvliyaKontey (Kontuś) in the Global and Local Context"]. In Tatarzy-historia i kultura. Sesja naukowa, 
Szreniawa, 26-27 czerwca 2009 [Tatars-History and Culture. Scientific Session, Szreniawa, 26-27 June 2009]. Edited by Selim Chazbijewicz. Szreniawa: Muzeum Narodowe Rolnictwa i Przemysłu Rolno-Spożywczego w Szreniawie, 2009. 20-25.

Zagórski, Bogusław R. [Ryszard]. “Orientalizm lub orientalność polskiej wspólnoty etnicznej i politycznej w aspekcie europejskim" ["Orientality and Orientalism of the Polish Ethnic and Political Community in the European Aspect"]. In Rzeczpospolita wielokulturowa-dobrodziejstwo czy obciażenie? [Multicultural Commonwealtha Blessing or a Burden?]. Edited by Jerzy Kłoczowski. Warszawa: Collegium Civitas and Polski Komitet do Spraw Unesco, 2009. 37-50.

Zagórski, Bogusław R. [Ryszard]. "Leopold Weiss or Muhammad Asad and His Polish Cultural Background." Paper presented at the international symposium "Mohammad Asad-A Life for Dialogue," King Faisal Center for Research and Islamic Studies, Riyadh, April 11-12, 2011.

Zaworska, Helena. Sztuka podróżowania. Poetyckie mity podróży ... [The Art of Travelling. Poetical Travel Myths ...]. Kraków: Wydawnictwo Literackie, 1980.

Żagiell, Ignacy. Podróż historyczna po Abissynii, Adel, Szoa, Nubii, u źródet Nilu, z opisaniem jego wodospadów, oraz po krajach podrównikowych, do Mekki i Medyny, Syryi i Palestyny, Konstantynopolu i po Archipelagu, przez D-ra Ig. KsięciaŻagiella ... z dodaniem matego stowniczka najużywańszych wyrazów arabskich [Historical Journey to Abyssinia, Adel, Shoa, Nubia, Sources of the Nile, With the Description of Its Waterfalls, and to the Equatorial Countries; to Mecca and Medina, Syria and Palestine, Constantinople and the Archipelago, by Dr. Prince Ignacy Żagiell ..., with the Addition of a Small Glossary of Most Frequently Used Arabic Words]. Wilno: Nakładem autora, Drukiem Józefa Zawadzkiego, 1884. [reprinted: Pelplin: Wydawnictwo "Bernardinum," 2012]. 